\title{
Targeting Early Dementia: Using Lipid Cubic Phase Nanocarriers to Cross the Blood-Brain Barrier
}

\author{
Joseph S. D'Arrigo ${ }^{+}$ \\ Cavitation-Control Technology Inc., Farmington, CT 06032, USA; cavcon@ntplx.net \\ + Current Address: Cav-Con Inc., Bellevue, WA 98007, USA.
}

Received: 22 January 2018; Accepted: 6 March 2018; Published: 7 March 2018

\begin{abstract}
Over the past decades, a frequent co-morbidity of cerebrovascular pathology and Alzheimer's disease has been observed. Numerous published studies indicate that the preservation of a healthy cerebrovascular endothelium can be an important therapeutic target. By incorporating the appropriate drug(s) into biomimetic (lipid cubic phase) nanocarriers, one obtains a multitasking combination therapeutic, which targets certain cell surface scavenger receptors, mainly class B type I (i.e., SR-BI), and crosses the blood-brain barrier. This targeting allows for various cell types related to Alzheimer's to be simultaneously searched out for localized drug treatment in vivo.
\end{abstract}

Keywords: Alzheimer's disease; biomimetic nanocarriers; blood-brain barrier; dementia; drug targeting; lipid cubic phase; nanoemulsion; SR-BI; scavenger receptors

\section{Introduction}

The fundamental involvement of the cerebrovasculature in the pathogenesis of common dementias, widely reported in the biomedical literature, has recently been reviewed (e.g., [1,2]). Small vessel disease is commonly found in patients who have other brain pathologies, such as plaques and tangles associated with neurodegenerative diseases; small vessel disease also increases the risk of Alzheimer's disease. Accordingly, vascular cognitive impairment and dementia (VCID) is the second leading cause of dementia, behind Alzheimer's disease, and is a frequent co-morbidity in Alzheimer's patients [3-9]. On a worldwide basis, 47 million people had dementia in 2016; of these dementia patients, $60-80 \%$ had Alzheimer's disease [4,10,11].

\section{Central Role of Endothelial Dysfunction}

It has been reported repeatedly that endothelial modulation and repair is feasible by pharmacological targeting [1,12-26] via scavenger receptor class B type I (SR-BI) (cf. [25]). As the detailed review by Mahringer et al. [27] points out, the blood-brain barrier (BBB) is equipped with several endocytic receptors at the luminal surface (i.e., the capillary endothelial membrane), including the SR-BI scavenger receptor. Furthermore, very recently published experimental work (in human-endothelial-cell monolayer cultures as well as in three-dimensional tissue-engineered human vessels) has demonstrated in detail that high-density lipoproteins (HDL), acting via scavenger receptors (specifically SR-BI), block $\beta$-amyloid uptake into endothelial cells both in experimental monolayers and probably in the intact human cerebrovascular endothelium [28] (cf. [29-31]).

Almer et al. [14] explain in their recent review that the integration of lipoprotein-related or apolipoprotein-targeted nanoparticles, as drug carriers, is an expanding concept in nanomedicine to exploit the intrinsic characteristics of lipoprotein particles as being the natural transporter of lipophilic compounds in human circulation. Discrete lipoprotein assemblies and lipoprotein-based biomimetics offer a versatile nanoparticle platform for constructing drug loaded, reconstituted or artificial lipoprotein particles for specific medical applications. As naturally occurring nanoassemblies, 
lipoprotein particles are not readily (nor rapidly) cleared by the mononuclear phagocyte system (of the liver and spleen) and remain in circulation for a longer period of time [14]. More recently, Srimanee et al. [12] further explain that receptor-mediated transcytosis (RMT) at the BBB occurs in three steps: (1) receptor-mediated endocytosis at the luminal (capillary endothelial lining/blood) side via ligands (i.e., lipoprotein-related, apolipoprotein-targeted nanoparticles) binding to specific membrane receptors (e.g., SR-BI); (2) transfer of endocytic vesicles through the cytoplasm; (3) and excytosis of the carried (small-molecule or biomolecular) drug at the abluminal (brain/endothelial) side. Currently, several receptors are known to be expressed on the luminal surface of the BBB, which include scavenger receptors (such as SR-BI) [12]. Particularly, SR-BI was found in bovine and porcine brain capillary endothelial cells (BCEC), and also expressed in murine brain. The rodent SR-BI was studied and showed the same structure/behavior as human SR-BI [12,13]. With regard to their own experimental work, Srimanee et al. [12] report that SR-BI are also involved (among several receptor types studied by their group) in the uptake of nanocomplexes into brain endothelial cells, and also mediate the transport of nanocomplexes across their BBB model. Moreover, other published studies have shown that lipophilic compounds bound to HDL (and probably to "HDL-like" nanoparticles as well) have the possibility to be internalized by a "piggy-back"-like mechanism [13]. It was shown that uptake of HDL-associated $\alpha$-tocopherol by porcine BCEC via SR-BI exceeded the uptake of HDL particles up to 13-fold, suggesting a selective uptake of this compound without the concomitant internalization of the lipoprotein (HDL) particle. Additional work has demonstrated apolipoprotein (apo) A-I expression in porcine brain capillaries [13]. Further research indicated that apoA-I, the major protein component of HDL, was effluxed by porcine BCEC (whereas the aortic endothelium did not efflux any detectable amount of apoA-I). ApoA-I-inducing compounds, such as cholesterol, could upregulate apoA-I in BCEC. These data toegether, suggested that apoA-I is effluxed apparently by the SR-BI receptor in porcine BCEC [13]. Moreover, Fung et al. [32] separately reported that SR-BI mediates the uptake and transcytosis of HDL across brain microvascular endothelial cells (i.e., across the blood-brain barrier). The authors assert that elucidating the mechanisms of HDL transcytosis across the BBB, in particular, may be pathologically significant, as its constituent apoA-I has been demonstrated to confer a protective effect against Alzheimer's disease. Using a combination of spinning-disc confocal and total internal reflection fluorescence microscopy, these authors examined the internalization and transcytosis of fluorescently labeled HDL by human primary brain microvascular endothelial cell monolayers. Using these approaches, these investigators reported that HDL internalization requires dynamin, but not clathrin heavy chain, and that its internalization and transcytosis are saturable. The authors concluded that these (and other reported) findings indicate that HDL transcytosis across the BBB involves a signaling pathway downstream of SR-BI. These investigators further argue that manipulation of HDL transcytosis across the BBB to increase delivery of plasma apoA-I may, in turn, facilitate increasing the transport of "HDL-like synthetic particles" containing therapeutic drugs across the BBB to treat neurodegenerative disorders such as Alzheimer's disease [32] (cf. [28,33-42]).

\section{Targeted Drug Treatment for Early Dementia}

This targeted drug delivery approach, using an apoA-I-based (SR-BI-mediated) therapeutic agent for treating the more common (late-onset) dementias, receives added impetus from continued findings of cerebrovascular pathology [1,43-53] and an apparent endothelium dysfunction [2,33-41,49,54-60] in both Alzheimer's disease and its major risk factors [1,2,53-72]. By incorporating drug candidates (such as Edaravone, docosahexaenoic acid (DHA), or antibody therapeutics) into the "lipid-coated microbubble/nanoparticle-derived" (LCM/ND) lipid nanoemulsion type (yielding particle sizes mostly $<0.1 \mu \mathrm{m}$ in diameter), known to be a successful drug carrier [73,74], one is likely to obtain a multitasking combination therapeutic capable of targeting cell surface SR-BI. This combination therapeutic would make it possible for various cell types, all potentially implicated in Alzheimer's disease (cf. [71,72]), to be simultaneously sought out and better reached for localized drug treatment of brain tissue in vivo. 
With regard to receptor-mediated membrane transport across the BBB, brain microvascular endothelial cells are believed to control iron uptake and efflux, under the direct guidance of neighboring astrocytes [75,76]. Detailed evidence has been reported recently [75] showing that human brain microvascular endothelial cells, which constitute most of the BBB, receive brain iron status information via paracrine signals from ensheathing astrocytes. Lastly, aging, obesity, and smoking are determinants of brain iron accumulation in human subjects [77] and all have been shown to be associated with the long-term incidence of Alzheimer's disease [25,50-52,54,55,65,78-80].

Note that the above-mentioned association of both obesity and diabetes with incidence of Alzheimer's disease has also renewed the interest in the main facilitative glucose transporter protein in the brain, GLUT-1, and its involvement in and probable contribution to neurodegenerative diseases [81-83]. More than two decades ago, it was already recognized that the normal human brain capillary endothelial cells have a high density of GLUT-1, whereas the cerebral microvessels in subjects with Alzheimer's disease showed a markedly decreased in GLUT-1 density when compared with age-matched controls [84,85]. More recently, Winkler et al. [86] demonstrated that GLUT-1 deficiency in the cerebral endothelium (but not in astrocytes) initiates BBB breakdown in a mouse model of Alzheimer's disease. These authors observed from their detailed experiments that reduced GLUT-1 expression (at the BBB) worsens Alzheimer's disease cerebrovascular degeneration, neuropathology, and cognitive function-suggesting that (cerebral endothelial) GLUT-1 may represent a therapeutic target for Alzheimer's disease vasculo-neuronal dysfunction and degeneration [86]. Furthermore, other investigators [87] (cf. [88]) have recently provided evidence for brain glucose dysregulation as a critical event in Alzheimer's disease pathogenesis that closely reflects both the severity of the neuropathology and the expression of symptoms in Alzheimer's disease. Moreover, abnormalities in brain glucose homeostasis may begin several years before the onset of clinical symptoms [87].

In summary, endothelial cells are the main component of the BBB, which is seriously disrupted in various neurological pathologies, including many neurodegenerative disorders [89-91]. An early BBB breakdown and/or dysfunction has been documented in Alzheimer's disease before dementia, neurodegeneration, and/or brain atrophy occur, and investigators have reported that targeting the BBB can influence the course of such neurological disorder [92]. Hence, vascular-targeted therapies become plausible for the prevention and treatment of common dementias [4,36,89,93-95]. In respect of vascular tone, vasodilation (mediated by nitric oxide or acetylcholine) is repressed whereas vasoconstriction (mediated by endothelin-1) is enhanced, thus contributing to endothelial dysfunction in Alzheimer's disease [90,96]. Also, $\beta$-amyloid can induce apoptosis and/or necrosis of brain endothelial cells. Presence of $\beta$-amyloid, as well as tau protein oligomers, leads to accumulation of inflammatory molecules in microvessels — which further fosters endothelial dysfunction [90,97-99]. Other cell types of the neurovascular unit are affected in Alzheimer's disease as well [90]. For example, deposition and aggregation of $\beta$-amyloid within vascular smooth muscle cells leads to inflammation, oxidative stress, impaired vasorelaxation, and disruption of BBB integrity. At the same time, midlife vascular risk factors such as hypertension, cardiovascular disease, diabetes, dyslipidemia, and obesity all increase the relative risk for Alzheimer's disease [89,100-103]. These co-morbidities are all characterized by low and/or dysfunctional HDL, which itself is an Alzheimer's risk factor. Namely (in addition to the widely reported lipid transport), HDL regulates vascular health via modulating vasorelaxation, inflammation, and oxidative stress as well as promoting endothelial cell survival and integrity [36,102,104]. Since SR-BI has already been identified as a major receptor for HDL (with its major constituent apoA-I) as well as for the earlier-described LCM/ND nanoemulsion [1,2], this multitasking lipid nanoemulsion can arguably serve as a targeted, apoA-I-based, (SR-BI-mediated) therapeutic agent for common (late-onset) dementias (cf. [28,33,35,37-42]). In this particular targeted delivery approach, the self-assembled HDL-related "lipid nanoemulsion particle" structure itself (after intravenous injection) likely binds to apoA-I in the blood plasma; subsequently, such apoA-I-targeted LCM/ND nanoemulsion particles are recognized by SR-BI receptors on various Alzheimer's-related cell types [73]. 


\section{Lipid-Coated Microbubble/Nanoparticle-Derived Nanoemulsion Type Contains Lipid Cubic Phase Nanocarriers}

The self-assembled LCM/ND lipid nanoemulsion comprises nonionic lipids exclusively (cf. [105,106]) throughout its coated microbubbles and/or related nanoparticles (i.e., related lipid polymorphs) supramolecular structures(s). This biobased lipid composition of LCM/ND nanoemulsions (i.e., glycerides and cholesterol compounds) is similar to lipids contained in several types of plasma lipoproteins; accordingly, when these LCM/ND nanoemulsion particles are injected into the bloodstream, they likely acquire (i.e., bind) plasma apolipoprotein(s)—including notably apoA-I [73]. Hence, the molecular composition of the LCM/ND nanoemulsion particles results in both microbubble/nanoparticle stability and marked targeting toward tumors and certain hyperproliferative disease lesions/sites; this very rapid targeting has been demonstrated to occur by an active uptake process, i.e., endocytosis-which likely involves certain "lipoprotein receptor"-mediated endocytic pathways [2].

The collection of powdered solid lipid surfactants used to produce LCM/ND lipid nanoemulsions, which is described with all structural details of the molecular components in the published patents covering this technology $[105,106]$, can be outlined as follows:

a. "a member selected from the group consisting of glycerol monoesters of saturated carboxylic acids containing from about 10 to about 18 carbon atoms ... ;

b. a sterol aromatic ester;

c. a member selected from the group consisting of sterols ... ;

d. a member selected from the group consisting of sterol esters of aliphatic acids containing from one to about 18 carbon atoms; $\ldots$ and

e. a member selected from the group consisting of glycerol, glycerol di-, or triesters of aliphatic acids containing from about 10 to about 18 carbon atoms ... ".

"The surfactant mixture of the present invention can be readily prepared by admixing components a through e in a weight ratio a:b:c:d:e of 2-4:0.5-1.5:0.5-1.5:0-1.5:0-1.5, respectively. Preferably ... the components of the surfactant mixture of the present invention are combined in a weight ratio a:b:c:d:e of 2-4:1:1:1:1. Since each of the components of the surfactant mixture of the present invention is a dry powder, the resultant admixture is conveniently obtained in a dry powdered form." In a particularly preferred form (i.e., "Example 1") of the invention, the "surfactant mixture was prepared in accordance with the present invention by admixing glycerol monolaurate, cholesterol benzoate, cholesterol, cholesterol acetate, and glycerol tripalmitate in a weight ratio of 3:1:1:1:1, respectively, to obtain a dry powdery surfactant mixture" $[105,106]$.

Importantly, monoglyceride is the largest single-lipid fraction (by wt $\%$ ) of the powdered solid lipid surfactants used to produce the (Filmix ${ }^{\circledR}$ ) LCM/ND nanoemulsions [73]. As a group, monoglycerides exhibit different phase behaviors when they are exposed to water [107] (cf. [108,109]). The ability to exist in several different phases is an important property of pure lipids and lipid mixtures; it depends upon temperature, hydration, and lipid class [107]. Although monoglycerides typically have poor water solubility, they have free hydroxyl groups which can hydrogen bond with water, surfactants, cosolvents, etc. As polar lipids, monoglycerides typically: (1) are better solvents for drugs; (2) act as cosurfactants which promote mutual solubility between excipients (i.e., inactive ingredients); (3) enhance water uptake; and (4) promote self-dispersibility of lipid formulations [110]. The above properties of monoglycerides place them in a lipid class known as "insoluble swelling amphiphiles". These lipid molecules form stable monolayers (at the air/water interface), but also swell in water to form liquid crystalline phases [111]. In their detailed review, Kaasgaard and Drummond [112] explain that these lyotropic (i.e., solvent induced) liquid crystalline phases of monoglycerides include the one-dimensional lamellar phase, which has been widely studied and employed as a model system for biomembranes and drug delivery applications. More recently studied are the structurally more complex two- and three-dimensional ordered (lyotropic) liquid crystalline phases, of which inverse hexagonal and cubic phases are two prominent examples. In agreement with numerous other 
investigators, Kaasgaard and Drummond also state that all these types of liquid crystalline phases are frequently stable in excess water, which facilitates the preparation of nanoparticle dispersions and makes them suitable candidates for the encapsulation and controlled release of drugs ([112]; cf. [113-119]).

In the "preferred form" of the LCM/ND nanoemulsion formulations (cf. $[105,106])$, the monoglyceride content employed consists entirely of the saturated variety. Using only saturated monoglyceride in such nanoemulsion formulations carries an additional benefit. Namely, saturated fatty chains (i.e., saturated acyl groups) are advantageous because they are incapable of undergoing peroxidation reactions, which would lessen the acceptable storage life (cf. [120]) of these ("oil-in-water") nanoemulsions.

The self-assembly of varied and useful dispersed cubic phases (among other liquid crystalline phases) depends heavily on the acyl chain length of the glycerides (primarily monoglycerides) placed in contact with water [73]. As Yaghmur et al. [119] point out, the significant interest in the formulation and the characterization of these complex and varied, self-assembled, liquid crystalline cubic phases is driven by both fundamental and practical considerations: they offer many advantages compared to conventional dispersed systems (such as simple or double emulsions) because of their confined equilibrium nanostructures with high interfacial area, their low viscosity, and their capabilities to solubilize a wide variety of active molecules. Therefore, there is great interest to utilize theses dispersed cubic phases for the administration of drugs, or for the formulation of new delivery systems [119].

The (lyotropic) cubic liquid crystalline phases may be classified into two distinct classes: bicontinuous cubic phases and micellar or discontinuous (e.g., type Fd3m) cubic phases. Representative illustrations, including suitable micrographs, of these dispersed cubic phases can be found in [107,112,114,121-124]. As Abraham et al. [125] explain, two alternate structural representations have been utilized to describe the bicontinuous cubic phases, one in terms of rod-like elements and the other in terms of folded surfaces, that is, infinite periodic minimal surfaces (IPMS) (alternatively, the representations in terms of nodal surfaces have been used to describe the dynamic structure of cubic phases). Three different "inverse bicontinuous" cubic lipid phases have been observed experimentally, having the symmetry Pn3m, Ia3d, and Im3m-corresponding to the following IPMS: the diamond type (D-surface), the gyroid type (G-type), and the primitive type (P-surface), respectively [125]. As reviewed by Garg et al. [107], monoglycerides spontaneously form bicontinuous cubic phases upon the addition of water, are relatively insoluble (allowing the formation of colloidal dispersions of cubic phases), and resistant to changes in temperature. Accordingly, lipid nanoparticles comprising interior liquid crystalline structures of curved lipid membranes (i.e., dispersed cubic phases) have been used to solubilize, encapsulate, and deliver medications to disease areas within the body [107].

Besides certain glyceride-based liquid crystalline systems displaying colloidal stability in excess water, the same important attribute has been documented for cholesterol and cholesterol esters-all of which are present in LCM/ND nanoemulsion formulations [73]. For example, cholesterol and its esters change the packing structure of lipids, and in high concentrations they are known to induce the formation of a liquid crystal phase [120]. In addition, Kuntsche and colleagues [126,127] have prepared lipid nanoparticles in the (mesomorphic or) liquid crystalline phase from cholesterol esters with saturated acyl chains. These investigators were motivated by the knowledge that many cholesterol esters are physiologic lipid compounds which can form liquid crystalline phases (thermotropic mesophases) and, hence, they were interested in their potential for the development of liquid crystalline nanoparticles as a carrier system for lipophilic drugs [127]. In accordance with the above observations and considerations, the substantial concentrations of cholesterol esters and cholesterol in the LCM/ND nanoemulsion formulation likely further contribute to the known long-term stability of this nanoemulsion (liquid crystalline) lipid nanoparticles in excess water, thereby providing a persistent carrier matrix upon exposure to liquids such as blood plasma [73]. 


\section{Promising Developments Regarding Supplementary Neurotherapy Using Targeted Sonoporation}

A completely separate advantage of such LCM/ND (drug delivery) nanoemulsion(s) stems from the characteristic lipid-coated microbubble subpopulation existing in this nanoemulsion type [1,2,73]. Over the past decade, neuroscientists have been exploring the use of ultrasound in combination with preformed (intravenous) microbubbles to temporarily open the BBB (cf. [128-149]), allowing drugs or the immune system to target brain tumors or Alzheimer's brain plaque in vivo effectively, repeatedly, and safely [150-156] in animals up to primates [150,157] and even in humans [157]. It is worth noting that this proposed mechanism of plaque burden reduction, by sonoporation (i.e., "loosening the tight junctions of the cells forming the BBB" via ultrasound irradiation $[158,159])$, might carry an additional effect. (Microbubble-assisted) sonoporation not only facilitates localized delivery of drugs and/or activated immune cells to target Alzheimer's brain plaque in vivo [158], but also facilitates (possibly by passive transport) reduction of $\beta$-amyloid plaque burden from brain tissue in a mouse model of Alzheimer's disease [160]. Specifically, this same mechanism might also function to counteract characteristic decreased "brain clearance" of neurotoxic $\beta$-amyloid "monomer" [160] - which has been described as a central event in the pathogenesis of Alzheimer's disease (cf. [1,2,161]).

The actual cellular and biophysical mechanisms of the reversible BBB opening process by sonoporation, when employing focused transcranial ultrasound coupled with injected preformed microbubbles, have been described further in other published studies over the last several years [1,162-168]. Also, representative illustrations depicting such an opening of the BBB, by postulated loosening of tight junctions (and other mechanisms), can be found in [141,164]. In the foreseeable future, taking full advantage of this ongoing, noninvasive, and targeted use of preformed (LCM/ND nanoemulsion-based) microbubbles to transiently and reversibly increase BBB permeability via sonoporation, while optimizing drug delivery efficiency (through judicious choice of acoustic parameters $[152,156])$ and minimizing side effects, may assist in advancing transcranial sonoporation to the clinic (cf. [1,167-182]).

\section{Lipid-Coated Microbubble/Nanoparticle-Derived Nanoemulsion Particles Function as Biomimetic Cubic Phase Nanotransporters}

As alluded to in Section 4, the previously documented similarities in lipid composition among HDL (as well as native and modified low-density lipoproteins (LDL)) and LCM/ND nanoemulsion particles can partially simulate or mimic the known heterogeneity (i.e., subpopulations or subspecies) of HDL particles (for a review, see [73]). Moreover, the above-mentioned scavenger receptor (i.e., either SR-BI (rodent) and/or CLA-1 (human) orthologs [29]) has been shown to be a multifunctional receptor able to bind a broad variety of ligands, including HDL, LDL, oxidized low-density lipoproteins (OxLDL), acetylated low-density lipoproteins (AcLDL), very low-density lipoproteins (VLDL), and chylomicron remnants [183-185]. The presence of amphipathic helices is a common feature of "exchangeable apolipoproteins", which are known to be the primary ligands (including notably apoA-I) for SR-BI [183].

One example of a reconstituted (biomimetic) lipoprotein complex utilizing the SR-BI cell surface receptor in the literature concerns manufactured (lipid) emulsions that were designed to mimic chylomicrons in vivo, and therefore were expected to acquire apolipoproteins upon incubation with serum [186]. The experimental data obtained led investigators to conclude that SR-BI is clearly involved in facilitating chylomicron (remnant) metabolism and might function as an initial recognition site for chylomicron remnants [185]. Note that, in this example, the "reconstituted lipoprotein vehicle" was at first constructed solely of lipids, and apolipoprotein(s) (needed for targeting) were acquired only after incubation with serum. This concept of a pure lipid nanocarrier, which can successfully acquire apolipoprotein(s) upon contact with blood plasma, is similarly described elsewhere in the literature. For example, Williams and Scanu [187] reported that phosphoglyceride liposomes, injected intravenously, pick up endogenous apoA-I; in vitro, phosphoglyceride liposomes incubated with plasma acquire apoA-I 
at the expense of HDL [73] (cf. [188]). Explanatory illustrations depicting the apoA-I chemical structure, the apoA-I conformation on discoidal and spherical HDL particles, and their relative sizes can be found in [189].

To conclude, self-assembled (colloidal mesophase) lipid nanoemulsions (e.g., [190-195]), particularly those predominantly containing dispersed cubic phase lipid nanoparticles (e.g., [196-200]), continue to receive growing attention in pharmaceutical and/or biological fields. The main reason behind much of this attention is the fact that nonlamellar lipid nanostructures, such as cubic liquid crystalline phases, have wide potential as delivery systems for numerous drugs, cosmetics, and food applications (e.g., [201-203]). Namely, using various lipids and their mixtures to form self-assembled nonlamellar nanostructures, it has continually been reported possible to successfully obtain stable colloidal dispersions of (liquid crystalline) lipid cubic phases with well-defined particle size and morphology (e.g., [202,203]). In particular, within the range of self-assembled phases in model surfactant-like lipid systems, Yaghmur et al. [204] further emphasized that monoglyceride-based lyotropic liquid crystalline phases are relatively unique owing to their rich polymorphism in water and potential application as drug nanocarriers (cf. [205] and Section 4 above). A recurring example of a largely monoglyceride-based drug delivery agent category (cf. Sections 4-6) is the multitasking LCM/ND nanoemulsion formulation. In this particular targeted delivery approach, the self-assembled lipid particle structure itself (upon intravenous injection of the LCM/ND nanoemulsion) is apparently successfully utilized as the active targeting ligand-which is directed via (adsorption of) plasma lipoproteins towards the appropriate receptors on the target cell surface. These dispersed liquid crystalline lipid particles, of the LCM/ND nanoemulsion formulation, are colloidally stable nanocarriers which very likely represent liquid-crystalline inverse-topology nanotransporters (nanocarriers), i.e., dispersed lipid cubic phases (cf. [73]).

\section{Conclusions}

The proposed multitasking combination therapeutic appears likely to display greater efficacy at different stages of Alzheimer's disease (cf. [72]). Furthermore, the effects on various cell types targeted may be additive, multiplicative, or otherwise synergistic [26]. As a result, this multitasking (drug delivery) therapeutic approach could represent a promising way to treat, delay, or even prevent the disease in the future [1,2]. In particular, LCM/ND (lipid) nanoemulsion particles have a composition (consisting of various glycerides, cholesterol, and cholesterol esters) similar to lipids contained in several plasma lipoproteins (i.e., resembles the lipid content of a "generic" lipoprotein $[184,190])$. Accordingly, when this specific nanoemulsion type is injected intravenously, its colloidally stable lipid particles apparently acquire apoA-I from the plasma and, subsequently, can be recognized by and bind to certain lipoprotein receptors (predominantly SR-BI) on various Alzheimer's-related cell types.

Acknowledgments: This research did not receive any specific grant from funding agencies in the public, commercial, or nonprofit sectors.

Conflicts of Interest: The authors declare no conflict of interest. J.S.D. is employed at Cav-Con Inc.

\section{References}

1. D'Arrigo, J.S. Alzheimer's disease, brain injury, and CNS nanotherapy in humans: Sonoporation augmenting drug targeting. Med. Sci. 2017, 5, 29.

2. D'Arrigo, J.S. Nanotherapy for Alzheimer's disease and vascular dementia: Targeting senile endothelium. Adv. Colloid Interface Sci. 2018, 251, 44-54. [CrossRef] [PubMed]

3. Cooper, L.L.; Mitchell, G.F. Aortic stiffness, cerebrovascular dysfunction, and memory. Pulse 2016, 4, 69-77. [CrossRef] [PubMed]

4. Dichgans, M.; Leys, D. Vascular cognitive impairment. Circ. Res. 2017, 120, 573-591. [CrossRef] [PubMed]

5. Greenberg, S.M. Vascular disease and neurodegeneration: Advancing together. Lancet Neurol. 2017, 16, 333.

6. Kalaria, R.N. Neuropathological diagnosis of vascular cognitive impairment and vascular dementia with implications for Alzheimer's disease. Acta Neuropathol. 2016, 131, 659-685. [CrossRef] [PubMed] 
7. Duncombe, J.; Kitamura, A.; Hase, Y.; Ihara, M.; Kalaria, R.N.; Horsburgh, K. Chronic cerebral hypoperfusion: A key mechanism leading to vascular cognitive impairment and dementia. Closing the translational gap between rodent models and human vascular cognitive impairment and dementia. Clin. Sci. 2017, 131, 2451-2468. [CrossRef] [PubMed]

8. Perrotta, M.; Lembo, G.; Carnevale, D. Hypertension and dementia: Epidemiological and experimental evidence revealing a detrimental relationship. Int. J. Mol. Sci. 2016, 17, 347. [CrossRef] [PubMed]

9. Sudduth, T.L.; Weekman, E.M.; Price, B.R.; Gooch, J.L.; Woolums, A.; Norris, C.M.; Wilcock, D.M. Time-course of glial changes in the hyperhomocysteinemia model of vascular cognitive impairment and dementia (VCID). Neuroscience 2017, 341, 42-51. [CrossRef] [PubMed]

10. Bhat, N.R. Vasculoprotection as a convergent, multi-targeted mechanism of anti-AD therapeutics and interventions. J. Alzheimers Dis. 2015, 46, 581-591. [CrossRef] [PubMed]

11. Alzheimer's Disease International. World Alzheimer Report 2016; Alzheimer's Disease International: London, UK, 2016. Available online: www.alz.co.uk/worldreport2016 (accessed on 20 February 2018).

12. Srimanee, A.; Regberg, J.; Hallbrink, M.; Vajragupta, O.; Langel, U. Role of scavenger receptors in peptide-based delivery of plasmid DNA across a blood-brain barrier model. Int. J. Pharm. 2016, 500, 128-135. [CrossRef] [PubMed]

13. De Boer, A.G.; van der Sandt, I.C.J.; Gaillard, P.J. The role of drug transporters at the blood-brain barrier. Annu. Rev. Pharmacol. Toxicol. 2003, 43, 629-656. [CrossRef] [PubMed]

14. Almer, G.; Mangge, H.; Zimmer, A.; Prassl, R. Lipoprotein-related and apolipoprotein-mediated delivery systems for drug targeting and imaging. Curr. Med. Chem. 2015, 22, 3631-3651. [CrossRef] [PubMed]

15. Preston, J.E.; Abbott, J.; Begley, D.J. Transcytosis of macromolecules at the blood-brain barrier. Adv. Pharmacol. 2014, 71, 147-163. [PubMed]

16. Di Marco, L.Y.; Venneri, A.; Farkas, E.; Evans, P.C.; Marzo, A.; Frangi, A.F. Vascular dysfunction in the pathogenesis of Alzheimer's disease-A review of endothelium-mediated mechanisms and ensuing vicious circles. Neurobiol. Dis. 2015, 82, 593-606. [CrossRef] [PubMed]

17. Salmina, A.B.; Inzhutova, A.I.; Malinovskaya, N.A.; Petrova, M.M. Endothelial dysfunction and repair in Alzheimer-type neurodegeneration: Neuronal and glial control. J. Alzheimers Dis. 2010, 22, 17-36. [CrossRef] [PubMed]

18. Tong, X.K.; Hamel, E. Simvastatin restored vascular reactivity, endothelial function and reduced string vessel pathology in a mouse model of cerebrovascular disease. J. Cereb. Blood Flow Metab. 2015, 35, 512-520. [CrossRef] [PubMed]

19. Carradori, D.; Gaudin, A.; Brambilla, D.; Andrieux, K. Application of nanomedicine to the CNS diseases. Int. Rev. Neurobiol. 2016, 130, 73-113. [PubMed]

20. Koster, K.P.; Thomas, R.; Morris, A.W.; Tai, L.M. Epidermal growth factor prevents oligomeric amyloid- $\beta$ induced angiogenesis deficits in vitro. J. Cereb. Blood Flow Metab. 2016, 36, 1865-1871. [CrossRef] [PubMed]

21. Zenaro, E.; Piacentino, G.; Constantin, G. The blood-brain barrier in Alzheimer's disease. Neurobiol. Dis. 2016, 107, 41-56. [CrossRef] [PubMed]

22. Qosa, H.; Mohamed, A.; Al Rihani, S.B.; Batarseha, Y.S.; Duong, Q.V.; Keller, J.N.; Kaddoumi, A. High-throughput screening for identification of blood-brain barrier integrity enhancers: A drug repurposing opportunity to rectify vascular amyloid toxicity. J. Alzheimers Dis. 2016, 53, 1499-1516. [CrossRef] [PubMed]

23. Hostenbach, S.; D'haeseleer, M.; Kooijman, R.; De Keyser, J. The pathophysiological role of astrocytic endothelin-1. Prog Neurobiol. 2016, 144, 88-102. [CrossRef] [PubMed]

24. Koizumi, K.; Wang, G.; Park, L. Endothelial dysfunction and amyloid- $\beta$-induced neurovascular alterations. Cell. Mol. Neurobiol. 2016, 36, 155-165. [CrossRef] [PubMed]

25. Goldwaser, E.L.; Acharya, N.K.; Sarkar, A.; Godsey, G.; Nagele, R.G. Breakdown of the cerebrovasculature and blood-brain barrier: A mechanistic link between diabetes mellitus and Alzheimer's disease. J. Alzheimers Dis. 2016, 54, 445-456. [CrossRef] [PubMed]

26. Bredesen, D.E. Reversal of cognitive decline: A novel therapeutic program. Aging (Albany, NY) 2014, 6, 707-717. [CrossRef] [PubMed]

27. Mahringer, A.; Reichel, V.; Ott, M.; MacLean, C.; Reimold, I.; Hollnack-Pusch, E.; Fricker, G. Overcoming the blood brain barrier: The challenge of brain drug targeting. J. Nanoneurosci. 2012, 2, 5-19. [CrossRef] 
28. Robert, J.; Button, E.B.; Stukas, S.; Boyce, G.K.; Gibbs, E.; Cowan, C.M.; Gilmour, M.; Cheng, W.H.; Soo, S.K.; Yuen, B.; et al. High-density lipoproteins suppress A $\beta$-induced PBMC adhesion to human endothelial cells in bioengineered vessels and in monoculture. Mol. Neurodegener. 2017, 12, 60. [CrossRef] [PubMed]

29. Vishnyakova, T.G.; Bocharov, A.V.; Baranova, I.N.; Chen, Z.; Remaley, A.T.; Csako, G.; Eggerman, T.L.; Patterson, A.P. Binding and internalization of lipopolysaccharide by CLA-1, a human orthologue of rodent scavenger receptor B1. J. Biol. Chem. 2003, 278, 22771-22780. [CrossRef] [PubMed]

30. Darlington, D.; Li, S.; Hou, H.; Habib, A.; Tian, J.; Gao, Y.; Ehrhart, J.; Sanberg, P.R.; Sawmiller, D.; Giunta, B.; et al. Human umbilical cord blood-derived monocytes improve cognitive deficits and reduce amyloid- $\beta$ pathology in PSAPP mice. Cell Transplant. 2015, 24, 2237-2250. [CrossRef] [PubMed]

31. Chang, E.H.; Rigotti, A.; Huerta, P. Age-related influence of the HDL receptor SR-BI on synaptic plasticity and cognition. Neurobiol. Aging 2009, 30, 407-419. [CrossRef] [PubMed]

32. Fung, K.Y.; Wang, C.; Nyegaard, S.; Heit, B.; Fairn, G.D.; Lee, W.L. SR-BI mediated transcytosis of HDL in brain microvascular endothelial cells is independent of caveolin, clathrin, and PDZK1. Front. Physiol. 2017, 8, 841. [CrossRef] [PubMed]

33. Robert, J.; Stukas, S.; Button, E.; Cheng, W.H.; Lee, M.; Fan, J.; Wilkinson, A.; Kulic, I.; Wright, S.D.; Wellington, C.L. Reconstituted high-density lipoproteins acutely reduce soluble brain A $\beta$ levels in symptomatic APP/PS1 mice. Biochim. Biophys. Acta 2016, 1862, 1027-1036. [CrossRef] [PubMed]

34. Armstrong, S.M.; Sugiyama, M.G.; Fung, K.Y.Y.; Gao, Y.; Wang, C.; Levy, A.S.; Azizi, P.; Roufaiel, M.; Zhu, S.N.; Neculai, D.; et al. A novel assay uncovers an unexpected role for SR-BI in LDL transcytosis. Cardiovasc. Res. 2015, 108, 268-277. [CrossRef] [PubMed]

35. Hottman, D.A.; Chernick, D.; Cheng, S.; Wang, Z.; Li, L. HDL and cognition in neurodegenerative disorders. Neurobiol. Dis. 2014, 72, 22-36. [CrossRef] [PubMed]

36. Velagapudi, S.; Yalcinkaya, M.; Piemontese, A.; Meier, R.; Norrelykke, S.F.; Perisa, D.; Rzepiela, A.; Stebler, M.; Stoma, S.; Zanoni, P.; et al. VEGF-A regulates cellular localization of SR-BI as well as transendothelial transport of HDL but not LDL. Arterioscler. Thromb. Vasc. Biol. 2017, 37, 794-803. [CrossRef] [PubMed]

37. Choi, H.J.; Seo, E.H.; Yi, D.; Sohn, B.K.; Choe, Y.M.; Byun, M.S.; Lee, J.M.; Woo, J.I.; Lee, D.Y. Amyloid-independent amnestic mild cognitive impairment and serum apolipoprotein A1 levels. Am. J. Geriatr. Psychiatry 2016, 24, 144-153. [CrossRef] [PubMed]

38. Kitamura, Y.; Usami, R.; Ichihara, S.; Kida, H.; Satoh, M.; Tomimoto, H.; Murata, M.; Oikawa, S. Plasma protein profiling for potential biomarkers in the early diagnosis of Alzheimer's disease. Neurol. Res. 2017, 39, 231-238. [CrossRef] [PubMed]

39. Lazarus, J.; Mather, K.A.; Armstrong, N.J.; Song, F.; Poljak, A.; Thalamuthu, A.; Lee, T.; Kochan, N.A.; Brodaty, H.; Wright, M.J.; et al. DNA methylation in the apolipoprotein-A1 gene is associated with episodic memory performance on healthy older individuals. J. Alzheimers Dis. 2015, 44, 175-182. [PubMed]

40. Ma, C.; Li, J.; Bao, Z.; Ruan, Q.; Yu, Z. Serum levels of apoA1 and apoA2 are associated with cognitive status in older men. Biomed. Res. Int. 2015, 2015, 481621. [CrossRef] [PubMed]

41. Slot, R.E.; Van Harten, A.C.; Kester, M.I.; Jongbloed, W.; Bouwman, F.H.; Teunissen, C.E.; Scheltens, P.; Veerhuis, R.; van der Flier, W.M. Apolipoprotein A1 in cerebrospinal fluid and plasma and progression to Alzheimer's disease in non-demented elderly. J. Alzheimers Dis. 2017, 56, 687-697. [CrossRef] [PubMed]

42. Yin, Z.G.; Li, L.; Cui, M.; Zhou, S.M.; Yu, M.M.; Zhou, H.D. Inverse relationship between apolipoprotein A-I and cerebral white matter lesions: A cross-sectional study in middle-aged and elderly subjects. PLoS ONE 2014, 9, e97113. [CrossRef] [PubMed]

43. Weekman, E.M.; Sudduth, T.L.; Caverly, C.N.; Kopper, T.J.; Phillips, O.W.; Powell, D.K.; Wilcock, D.M. Reduced efficacy of anti-A $\beta$ immunotherapy in a mouse model of amyloid deposition and vascular cognitive impairment comorbidity. J. Neurosci. 2016, 36, 9896-9907. [CrossRef] [PubMed]

44. Nelson, A.R.; Sweeney, M.D.; Sagare, A.P.; Zlokovic, B.V. Neurovascular dysfunction and neurodegeneration in dementia and Alzheimer's disease. Biochim. Biophys. Acta 2016, 1862, 887-900. [CrossRef] [PubMed]

45. Kapasi, A.; Schneider, J.A. Vascular contributions to cognitive impairment, clinical Alzheimer's disease, and dementia in older persons. Biochim. Biophys. Acta 2016, 1862, 878-886. [CrossRef] [PubMed]

46. McAleese, K.L.; Alafuzoff, I.; Charidimou, A.; De Reuck, J.; Grinberg, L.T.; Hainsworth, A.H.; Hortobagyi, T.; Ince, P.; Jellinger, K.; Gao, J.; et al. Post-mortem assessment in vascular dementia: Advances and aspirations. BMC Med. 2016, 14, 129. [CrossRef] [PubMed] 
47. Noh, Y.; Seo, S.W.; Jeon, S.; Lee, J.M.; Kim, J.S.; Lee, J.H.; Kim, J.H.; Kim, G.H.; Ye, B.S.; Cho, H.; et al. The role of cerebrovascular disease in amyloid deposition. J. Alzheimers Dis. 2016, 54, 1015-1026. [CrossRef] [PubMed]

48. Hishikawa, N.; Fukui, Y.; Sato, K.; Kono, S.; Yamashita, T.; Ohta, T.; Deguchi, K.; Abe, K. Cognitive and affective functions in Alzheimer's disease patients with metabolic syndrome. Eur. J. Neurol. 2016, 23, 339-345. [CrossRef] [PubMed]

49. Gutierrez, J.; Honig, L.; Elkind, M.S.; Mohr, J.P.; Goldman, J.; Dwork, A.J.; Morgello, S.; Marshall, R.S. Brain arterial aging and its relationship to Alzheimer dementia. Neurology 2016, 86, 1507-1515. [CrossRef] [PubMed]

50. Nagata, K.; Yamazaki, T.; Takano, D.; Maeda, T.; Fujimaki, Y.; Nakase, T.; Sato, Y. Cerebral circulation in aging. Ageing Res. Rev. 2016, 30, 49-60. [CrossRef] [PubMed]

51. Calabrese, V.; Giordano, J.; Signorile, A.; Ontario, M.L.; Castorina, S.; de Pasquale, C.; Eckert, G.; Calabrese, E.J. Major pathogenic mechanisms in vascular dementia: Roles of cellular stress response and hormesis inneuroprotection. J. Neurosci. Res. 2016, 94, 1588-1603. [CrossRef] [PubMed]

52. Toth, P.; Tarantini, S.; Csiszar, A.; Ungvari, Z.I. Functional vascular contributions to cognitive impairment and dementia: Mechanisms and consequences of cerebral autoregulatory dysfunction, endothelial impairment, and neurovascular uncoupling in aging. Am. J. Physiol. Heart Circ. Physiol. 2017, 312, H1-H20. [CrossRef] [PubMed]

53. Devraj, K.; Poznanovic, S.; Spahn, C.; Schwall, G.; Harter, P.N.; Mittelbronn, M.; Antoniello, K.; Paganetti, P.; Muhs, A.; Heilemann, M.; et al. BACE-1 is expressed in the blood-brain barrier endothelium and is upregulated in a murine model of Alzheimer's disease. J. Cereb. Blood Flow Metab. 2016, 36, 1281-1294. [CrossRef] [PubMed]

54. Chao, A.C.; Lee, T.C.; Juo, S.H.; Yang, D.I. Hyperglycemia increases the production of amyloid $\beta$-peptide leading to decreased endothelial tight junction. CNS Neurosci. Ther. 2016, 22, 291-297. [CrossRef] [PubMed]

55. Khalil, R.B.; Khoury, E.; Koussa, S. Linking multiple pathogenic pathways in Alzheimer's disease. World J. Psychiatry 2016, 6, 208-214. [CrossRef] [PubMed]

56. Festoff, B.W.; Sajja, R.K.; van Dreden, P.; Cucullo, L. HGMB1 and thrombin mediate the blood-brain barrier dysfunction acting as biomarkers of neuroinflammation and progression to neurodegeneration in Alzheimer's disease. J. Neuroinflamm. 2016, 13, 194. [CrossRef] [PubMed]

57. Gangoda, S.V.; Butlin, M.; Gupta, V.; Chung, R.; Avolio, A. Pulsatile stretch alters expression and processing of amyloid precursor protein in human cerebral endothelial cells. J. Hypertens. 2016, 34, e24. [CrossRef]

58. Roberts, A.M.; Jagadapillai, R.; Vaishnav, R.A.; Friedland, R.P.; Drinovac, R.; Lin, X.; Gozal, E. Increased pulmonary arteriolar tone associated with lung oxidative stress and nitric oxide in a mouse model of Alzheimer's disease. Physiol. Rep. 2016, 4, e12953. [CrossRef] [PubMed]

59. Shang, S.; Yang, Y.M.; Zhang, H.; Tian, L.; Jiang, J.S.; Dong, Y.B.; Zhang, K.; Li, B.; Zhao, W.D.; Fang, W.G.; et al. Intracerebral GM-CSF contributes to transendothelial monocyte migration in APP/PS1 Alzheimer's disease mice. J. Cereb. Blood Flow Metab. 2016, 36, 1987-1991. [CrossRef] [PubMed]

60. Austin, S.A.; Katusic, Z.S. Loss of endothelial nitric oxide synthase promotes p25 generation and tau phosphorylation in a murine model of Alzheimer's disease. Circ. Res. 2016, 119, 1128-1134. [CrossRef] [PubMed]

61. Katusic, Z.S.; Austin, S.A. Neurovascular protective function of endothelial nitric oxide. Circ. J. 2016, 80, 1499-1503. [CrossRef] [PubMed]

62. Wang, L.; Du, Y.; Wang, K.; Xu, G.; Luo, S.; He, G. Chronic cerebral hypoperfusion induces memory deficits and facilitates A $\beta$ generation in C57BL/6J mice. Exp. Neurol. 2016, 283, 353-364. [CrossRef] [PubMed]

63. Kyrtsos, C.R.; Baras, J.S. Modeling the role of the glymphatic pathway and cerebral blood vessel properties in Alzheimer's disease pathogenesis. PLoS ONE 2015, 10, e0139574. [CrossRef] [PubMed]

64. Kalaria, R.N.; Akinyemi, R.; Ihara, M. Stroke injury, cognitive impairment and vascular dementia. Biochim. Biophys. Acta 2016, 1862, 915-925. [CrossRef] [PubMed]

65. Khan, A.; Kalaria, R.N.; Corbett, A.; Ballard, C. Update on vascular dementia. J. Geriatr. Psychiatry Neurol. 2016, 29, 281-301. [CrossRef] [PubMed]

66. Austin, S.A.; Santhanam, A.V.; d'Uscio, L.V.; Katusic, Z.S. Regional heterogeneity of cerebral microvessels and brain susceptibility to oxidative stress. PLoS ONE 2015, 10, e0144062. [CrossRef] [PubMed]

67. Toda, N.; Okamura, T. Cigarette smoking impairs nitric oxide-mediated cerebral blood flow increase: Implications for Alzheimer's disease. J. Pharmacol. Sci. 2016, 131, 223-232. [CrossRef] [PubMed] 
68. Uiterwijk, R.; Huijts, M.; Staals, J.; Rouhl, R.P.; De Leeuw, P.W.; Kroon, A.A.; van Oostenbrugge, R.J. Endothelial activation is associated with cognitive performance in patients with hypertension. Am. J. Hypertens. 2016, 29, 464-469. [CrossRef] [PubMed]

69. Kamat, P.K.; Kyles, P.; Kalani, A.; Tyagi, N. Hydrogen sulfide ameliorates homocysteine-induced Alzheimer's disease-like pathology, blood-brain barrier disruption, and synaptic disorder. Mol. Neurobiol. 2016, 53, 2451-2467. [CrossRef] [PubMed]

70. Iadecola, C. Untangling neurons with endothelial nitric oxide. Circ. Res. 2016, 119, 1052-1054. [CrossRef] [PubMed]

71. Wang, Y.J. Lessons from immunotherapy for Alzheimer's disease. Nat. Rev. Neurol. 2014, 10, 188-189. [CrossRef] [PubMed]

72. Krstic, D.; Knuesel, I. Deciphering the mechanism underlying late-onset Alzheimer's disease. Nat. Rev. Neurol. 2013, 9, 25-34. [CrossRef] [PubMed]

73. D'Arrigo, J. Stable Nanoemulsions: Self-Assembly in Nature and Nanomedicine; Elsevier: Amsterdam, The Netherlands, 2011; 415p, ISBN 978-0-444-53798-0.

74. Barbarese, E.; Ho, S.Y.; D'Arrigo, J.S.; Simon, R.H. Internalization of microbubbles by tumor cells in vivo and in vitro. J. Neurooncol. 1995, 26, 25-34. [CrossRef] [PubMed]

75. Beydoun, R.; Hamood, M.A.; Gomez Zubeita, M.; Kondapalli, K.C. Na+/H+ exchanger 9 regulates iron mobilization at the blood-brain barrier in response to iron starvation. J. Biol. Chem. 2017, 292, 4293-4301. [CrossRef] [PubMed]

76. McCarthy, R.C.; Kosman, D.J. Iron transport across the blood-brain barrier: Development, neurovascular regulation and cerebral amyloid angiopathy. Cell. Mol. Life Sci. 2015, 72, 709-727. [CrossRef] [PubMed]

77. Pirpamer, L.; Hofer, E.; Gesierich, B.; De Guio, F.; Freudenberger, P.; Seiler, S.; Duering, M.; Jouvent, E.; Duchesnay, E.; Dichgans, M.; et al. Determinants of iron accumulation in the normal aging brain. Neurobiol. Aging 2016, 43, 149-155. [CrossRef] [PubMed]

78. Dalkara, T.; Alarcon-Martinez, L. Cerebral microvascular pericytes and neurogliovascular signaling in health and disease. Brain Res. 2015, 1623, 3-17. [CrossRef] [PubMed]

79. Daulatzai, M.A. Cerebral hypoperfusion and glucose hypometabolism: Key pathophysiological modulators promote neurodegeneration, cognitive impairment, and Alzheimer's disease. J. Neurosci. Res. 2017, 95, 943-972. [CrossRef] [PubMed]

80. Tarantini, S.; Tran, C.H.; Gordon, G.R.; Ungvari, Z.; Csiszar, A. Impaired neurovascular coupling in aging and Alzheimer's disease: Contribution of astrocyte dysfunction and endothelial impairment to cognitive decline. Exp. Gerontol. 2016, 94, 52-58. [CrossRef] [PubMed]

81. Barros, L.F.; San Martin, A.; Ruminot, I.; Sandoval, P.Y.; Fernandez-Moncada, I.; Baeza-Lehnert, F.; Arce-Molina, R.; Contreras-Baeza, Y.; Cortés-Molina, F.; Galaz, A.; et al. Near-critical GLUT1 and neurodegeneration. J. Neurosci. Res. 2017, 95, 2267-2274. [CrossRef] [PubMed]

82. Jais, A.; Solas, M.; Backes, H.; Chaurasia, B.; Kleinridders, A.; Theurich, S.; Mauer, J.; Steculorum, S.M.; Hampel, B.; Goldau, J.; et al. Myeloid-cell derived VEGF maintains brain glucose uptake and limits cognitive impairment in obesity. Cell 2016, 165, 882-895. [CrossRef] [PubMed]

83. Keaney, J.; Campbell, M. The dynamic blood-brain barrier. FEBS J. 2015, 282, 4067-4079. [CrossRef] [PubMed]

84. Harik, S.I. Changes in the glucose transporter of brain capillaries. Can. J. Physiol. Pharmacol. 1992, 70 (Suppl. 1), S113-S117. [CrossRef] [PubMed]

85. Horwood, N.; Davies, D.C. Immunolabelling of hippocampal microvessel glucose transporter protein is reduced in Alzheimer's disease. Virchows Arch. 1994, 425, 69-72. [CrossRef] [PubMed]

86. Winkler, E.A.; Nishida, Y.; Sagare, A.P.; Rege, S.V.; Bell, R.D.; Perlmutter, D.; Sengillo, J.D.; Hillman, S.; Kong, P.; Nelson, A.R.; et al. GLUT1 reductions exacerbate Alzheimer's disease vasculo-neuronal dysfunction and degeneration. Nat. Neurosci. 2015, 18, 521-533. [CrossRef] [PubMed]

87. An, Y.; Varma, V.R.; Varma, S.; Casanova, R.; Dammer, E.; Pletnikova, O.; Chia, C.W.; Egan, J.M.; Ferrucci, L.; Troncoso, J.; et al. Evidence for brain glucose dysregulation in Alzheimer's disease. Alzheimer's Dement. 2017, 2017, 1-12. [CrossRef]

88. Yamazaki, Y.; Kanekiyo, T. Blood-brain barrier dysfunction and the pathogenesis of Alzheimer's disease. Int. J. Mol. Sci. 2017, 18, 1965. [CrossRef] [PubMed]

89. Kelleher, R.J.; Soiza, R.L. Evidence of endothelial dysfunction in the development of Alzheimer's disease: Is Alzheimer's a vascular disorder? Am. J. Cardiovasc. Dis. 2013, 3, 197-226. [PubMed] 
90. Tenreiro, M.M.; Ferreira, R.; Bernardino, L.; Brito, M.A. Cellular response of the blood-brain barrier to injury: Potential biomarkers and therapeutic targets for brain regeneration. Neurobiol. Dis. 2016, 91, 262-273. [CrossRef] [PubMed]

91. Yoon, C.Y.; Steffen, L.M.; Gross, M.D.; Launer, L.J.; Odegaard, A.; Reiner, A.; Sanchez, O.; Yaffe, K.; Sidney, S.; Jacobs, D.R., Jr. Circulating cellular adhesion molecules and cognitive function: The coronary artery risk development in young adults study. Front. Cardiovasc. Med. 2017. [CrossRef] [PubMed]

92. Montagne, A.; Zhao, Z.; Zlokovic, B.V. Alzheimer's disease: A matter of blood-brain barrier dysfunction? J. Exp. Med. 2017, 214, 3151-3169. [CrossRef] [PubMed]

93. Beishon, L.; Haunton, V.J.; Panerai, R.B.; Robinson, T.G. Cerebral hemodynamics in mild cognitive impairment: A systematic review. J. Alzheimers Dis. 2017, 59, 369-385. [CrossRef] [PubMed]

94. Love, S.; Miners, J.S. Small vessel disease, neurovascular regulation and cognitive impairment: Post-mortem studies reveal a complex relationship, still poorly understood. Clin. Sci. (Lond.) 2017, 131, 1579-1589. [CrossRef] [PubMed]

95. Wang, P.; Wu, Q.; Wu, W.; Li, H.; Guo, Y.; Yu, P.; Gao, G.; Shi, Z.; Zhao, B.; Chang, Y.Z. Mitochondrial ferritin deletion exacerbates $\beta$-amyloid-induced neurotoxicity in mice. Oxid. Med. Cell Longev. 2017, 2017, 1020357. [CrossRef] [PubMed]

96. Lourenco, C.F.; Ledo, A.; Barbosa, R.M.; Laranjinha, J. Neurovascular uncoupling in the triple transgenic model of Alzheimer's disease: Impaired cerebral blood flow response to neuronal-derived nitric oxide signaling. Exp. Neurol. 2017, 291, 36-43. [CrossRef] [PubMed]

97. Castillo-Carranza, D.L.; Nilson, A.N.; Van Skike, C.E.; Jahrling, J.B.; Patel, K.; Garach, P.; Gerson, J.E.; Sengupta, U.; Abisambra, J.; Nelson, P.; et al. Cerebral microvascular accumulation of tau oligomers in Alzheimer's disease and related tauopathies. Aging Dis. 2017, 8, 257-266. [CrossRef] [PubMed]

98. Dudvarski Stankovic, N.; Teodorczyk, M.; Ploen, R.; Zipp, F.; Schmidt, M.H. Microglia-blood vessel interactions: A double-edged sword in brain pathologies. Acta. Neuropathol. 2016, 131, 347-363. [CrossRef] [PubMed]

99. Michalicova, A.; Banks, W.A.; Legath, J.; Kovac, S.A. Tauopathies_Focus on changes at the neurovascular unit. Curr. Alzheimer Res. 2017, 14, 790-801. [CrossRef] [PubMed]

100. Sorop, O.; Olver, T.D.; van deWouw, J.; Heinonen, I.; van Duin, R.W.; Duncker, D.J.; Merkus, D. The microcirculation: A key player in obesity-associated cardiovascular disease. Cardiovasc. Res. 2017, 113, 1035-1045. [CrossRef] [PubMed]

101. Lee, L.L.; Aung, H.H.; Wilson, D.W.; Anderson, S.E.; Rutledge, J.C.; Rutkowsky, J.M. Triglyceride-rich lipoprotein lipolysis products increase blood-brain barrier transfer coefficient and induce astrocyte lipid droplets and cell stress. Am. J. Cell Physiol. 2017, 312, C500-C516. [CrossRef] [PubMed]

102. Stukas, S.; Robert, J.; Wellington, C.L. High-density lipoproteins and cerebrovascular integrity in Alzheimer's disease. Cell Metab. 2014, 19, 574-591. [CrossRef] [PubMed]

103. Swaminathan, S.K.; Ahlschwede, K.M.; Sarma, V.; Curran, G.L.; Omtri, R.S.; Decklever, T.; Lowe, V.J.; Poduslo, J.F.; Kandimalla, K.K. Insulin differentially affects the distribution kinetics of amyloid $\beta 40$ and 42 in plasma and brain. J. Cereb. Blood Flow Metab. 2017. [CrossRef] [PubMed]

104. Guilaine, B.; Emily, B.; Sonja, S.; Cheryl, W. The pleiotropic vasoprotective functions of high density lipoproteins (HDL). J. Biomed. Res. 2017. [CrossRef]

105. D'Arrigo, J. Surfactant Mixtures, Stable Gas-in-Liquid Emulsions, and Methods for the Production of such Emulsions from Said Mixtures. U.S. Patent No. 4,684,479A, 4 August 1987.

106. D'Arrigo, J. Method for the Production of Medical-Grade Lipid-Coated Microbubbles, Paramagnetic Labeling of such Microbubbles and Therapeutic Uses of Microbubbles. U.S. Patent No. 5,215,680A, 1 July 1993.

107. Garg, G.; Saraf, Sh.; Saraf, Sw. Cubosomes: An overview. Biol. Pharm. Bull. 2007, 30, 350-353. [CrossRef] [PubMed]

108. Tanford, C. The Hydrophobic Effect: Formation of Micelles and Biological Membranes; Wiley: New York, NY, USA, 1973; 200p.

109. Boyd, B.J.; Whittaker, D.V.; Khoo, S.M.; Davey, G. Lyotropic liquid crystalline phases formed from glycerate surfactants as sustained release drug delivery systems. Int. J. Pharm. 2006, 309, 218-226. [CrossRef] [PubMed]

110. Pouton, C.W. Properties and uses of common formulation lipids, surfactants and cosurfactants. In Proceedings of the AAPS Workshop, Effective Utilization of Lipid-Based Systems to Enhance the Delivery of Poorly Soluble Drugs: Physicochemical, Biopharmaceutical and Product Development Considerations, Bethesda, MD, USA, 5-6 March 2007; Constantinides, P.P., Porter, C.J.H., Eds.; AAPS: Arlington, VA, USA, 2007.

111. Small, D.M. The behavior of biological lipids. Pure Appl. Chem. 1981, 53, 2095-2103. [CrossRef] 
112. Kaasgaard, T.; Drummond, C.J. Ordered 2-D and 3-D nano-structured amphiphile self-assembly materials stable in excess solvent. Phys. Chem. Chem. Phys. 2006, 8, 4957-4975. [CrossRef] [PubMed]

113. Shearman, G.C.; Khoo, B.J.; Motherwell, M.L.; Brakke, K.A.; Ces, O.; Conn, C.E.; Seddon, J.M.; Templer, R.H. Calculations of and evidence for chain packing stress in inverse lyotropic bicontinuous cubic phases. Langmuir 2007, 23, 7276-7285. [CrossRef] [PubMed]

114. Rizwan, S.B.; Dong, Y.D.; Boyd, B.J.; Rades, T.; Hook, S. Characterization of bicontinuous cubic liquid crystalline systems of phytantriol and water using cryo field emission scanning electron microscopy (cryo FESEM). Micron 2007, 38, 478-485. [CrossRef] [PubMed]

115. Yaghmur, A.; de Campo, L.; Sagalowicz, L.; Leser, M.E.; Glatter, O. Emulsified microemulsions and oil-containing liquid crystalline phases. Langmuir 2005, 21, 569-577. [CrossRef] [PubMed]

116. Yaghmur, A.; de Campo, L.; Sagalowicz, L.; Leser, M.E.; Glatter, O. Control of the internal structure of MLO-based isasomes by the addition of diglycerol monooleate and soybean phosphatidylcholine. Langmuir 2006, 22, 9919-9927. [CrossRef] [PubMed]

117. Gustafsson, J.; Ljusberg-Wahren, H.; Almgren, M.; Larsson, K. Submicron particles of reversed lipid phases in water stabilized by a nonionic amphiphilic polymer. Langmuir 1997, 13, 6964-6971. [CrossRef]

118. De Campo, L.; Yaghmur, A.; Sagalowicz, L.; Leser, M.E.; Watzke, H.; Glatter, O. Reversible phase transitions in emulsified nanostructured lipid systems. Langmuir 2004, 20, 5254-5261. [CrossRef] [PubMed]

119. Yaghmur, A.; de Campo, L.; Salentinig, S.; Sagalowicz, L.; Leser, M.E.; Glatter, O. Oil-loaded monolinolein-based particles with confined inverse discontinuous cubic structure (Fd3m). Langmuir 2006, 22, 517-521. [CrossRef] [PubMed]

120. Amselem, S.; Friedman, D. Solid Fat Nanoemulsions. U.S. Patent No. 5,662,932A, 2 September 1997.

121. Larsson, K. Aqueous dispersions of cubic lipid-water phases. Curr. Opin. Colloid Interface Sci. 2000, 5, 64-69. [CrossRef]

122. Luzzati, V. Biological significance of lipid polymorphism: The cubic phases. Curr. Opin. Struct. Biol. 1997, 7, 661-668. [CrossRef]

123. Seddon, J.M.; Zeb, N.; Templer, R.H.; McElhaney, R.N.; Mannock, D.A. An Fd3m lyotropic cubic phase in a binary glycolipid/water system. Langmuir 1996, 12, 5250-5253. [CrossRef]

124. Sagalowicz, L.; Leser, M.E.; Watzke, H.J.; Michel, M. Monoglyceride self-assembly structures as delivery vehicles. Trends Food Sci. Tech. 2006, 17, 204-214. [CrossRef]

125. Abraham, T.; Hato, M.; Harai, M. Glycolipid based cubic nanoparticles: Preparation and structural aspects. Colloids Surf. B Biointerfaces 2004, 35, 107-117. [CrossRef] [PubMed]

126. Kuntsche, J.; Koch, M.H.J.; Drechsler, M.; Bunjes, H. Crystallization behavior of supercooled smectic cholesteryl myristate nanoparticles containing phospholipids as stabilizers. Colloids Surf. B Biointerfaces 2005, 44, 25-35. [CrossRef] [PubMed]

127. Kuntsche, J.; Westesen, K.; Drechsler, M.; Koch, M.H.J.; Bunjes, H. Supercooled smectic nanoparticles: A potential novel carrier system for poorly water-soluble drugs. Pharm. Res. 2004, 21, 1834-1843. [CrossRef] [PubMed]

128. Bing, C.; Ladouceur-Wodzak, M.; Wanner, C.R.; Shelton, J.M.; Richardson, J.A.; Chopra, R. Trans-cranial opening of the blood-brain barrier in targeted regions using a stereotaxic brain axis and focused ultrasound energy. J. Ther. Ultrasound 2014, 2. [CrossRef] [PubMed]

129. Lammers, T.; Koczera, P.; Fokong, S.; Gremse, F.; Ehling, J.; Vogt, M.; Pich, A.; Storm, G.; van Zandvoort, M.; Kiessling, F. Theranostic USPIO-loaded microbubbles for mediating and monitoring blood-brain barrier permeation. Adv. Funct. Mater. 2015, 25, 36-43. [CrossRef] [PubMed]

130. Marquet, F.; Tung, Y.S.; Teichert, T.; Ferrera, V.P.; Konofagou, E.E. Noninvasive, transient and selective blood-brain barrier opening in non-human primates in vivo. PLoS ONE 2011, 6, e22598. [CrossRef] [PubMed]

131. Goliaei, A.; Adhikari, U.; Berkowitz, M.L. Opening of the blood-brain barrier tight junction due to shock wave induced bubble collapse: A molecular dynamics simulation study. ACS Chem. Neurosci. 2015, 6, 1296-1301. [CrossRef] [PubMed]

132. Adhikari, U.; Goliaei, A.; Berkowitz, M.L. Mechanism of membrane poration by shock wave induced nanobubble collapse: A molecular dynamics study. J. Phys. Chem. B 2015, 119, 6225-6234. [CrossRef] [PubMed]

133. Delalande, A.; Leduc, C.; Midoux, P.; Postema, M.; Pichon, C. Efficient gene delivery by sonoporation is associated with microbubble entry into cells and the clathrin-dependent endocytosis pathway. Ultrasound Med. Biol. 2015, 41, 1913-1926. [CrossRef] [PubMed] 
134. Kotopoulis, S.; Dimcevski, G.; Gilja, O.H.; Hoem, D.; Postema, M. Treatment of human pancreatic cancer using combined ultrasound, microbubbles, and gemcitabine: A clinical case study. Med. Phys. 2013, 40, 072902. [CrossRef] [PubMed]

135. Kotopoulis, S.; Delalande, A.; Popa, M.; Mamaeva, V.; Dimcevski, G.; Gilja, O.H.; Postema, M.; Gjertsen, B.T.; McCormack, E. Sonoporation-enhanced chemotherapy significantly reduces primary tumour burden in an orthotopic pancreatic cancer xenograft. Mol. Imaging Biol. 2014, 16, 53-62. [CrossRef] [PubMed]

136. D'Arrigo, J.S. Nanotherapy for Alzheimer's. Chem. Eng. News 2015, 93, 2.

137. Paefgen, V.; Doleschel, D.; Kiessling, F. Evolution of contrast agents for ultrasound imaging and ultrasound-mediated drug delivery. Front. Pharm. 2015, 6, 197. [CrossRef] [PubMed]

138. Qin, J.; Wang, T.Y.; Willmann, J.K. Sonoporation: Applications for cancer therapy. Adv. Exp. Med. Biol. 2016, 880, 263-291. [PubMed]

139. Aubry, J.F.; Tanter, M. MR-guided transcranial focused ultrasound. Adv. Exp. Med. Biol. 2016, 880, 97-111. [PubMed]

140. Castle, J.; Feinstein, S.B. Drug and gene delivery using sonoporation for cardiovascular disease. Adv. Exp. Med. Biol. 2016, 880, 331-338. [PubMed]

141. Burgess, A.; Hynynen, K. Microbubble-assisted ultrasound for drug delivery in the brain and central nervous system. Adv. Exp. Med. Biol. 2016, 880, 293-308. [PubMed]

142. Bouakaz, A.; Zeghimi, A.; Doinikov, A.A. Sonoporation: Concept and mechanisms. Adv. Exp. Med. Biol. 2016, 880, 175-189. [PubMed]

143. Skachkov, I.; Luan, Y.; van der Steen, A.F.W.; de Jong, N.; Kooiman, K. Targeted microbubble mediated sonoporation of endothelial cells in vivo. IEEE Trans. Ultrason. Ferrelectr. Freq. Control 2014, 61, 1661-1667. [CrossRef] [PubMed]

144. Caskey, C.F.; Stieger, S.M.; Qin, S.; Dayton, P.A.; Ferrara, K.W. Direct observations of ultrasound microbubble contrast agent interaction with the microvessel wall. J. Acoust. Soc. Am. 2007, 122, 1191-1200. [CrossRef] [PubMed]

145. Choi, J.J.; Wang, S.; Brown, T.R.; Small, S.A.; Duff, K.E.; Konofagou, E.E. Noninvasive and transient blood-brain barrier opening in the hippocampus of Alzheimer's double transgenic mice using focused ultrasound. Ultrason. Imaging 2008, 30, 189-200. [CrossRef] [PubMed]

146. Choi, J.J.; Selert, K.; Vlachos, F.; Wong, A.; Konofagou, E.E. Noninvasive and localized neuronal delivery using short ultrasonic pulses and microbubbles. Proc. Natl. Acad. Sci. USA 2011, 108, 16539-16544. [CrossRef] [PubMed]

147. Konofagou, E.E. Optimization of the ultrasound-induced blood-brain barrier opening. Theranostics 2012, 2, 1223-1237. [CrossRef] [PubMed]

148. McDannold, N.; Arvanitis, C.D.; Vykhodtseva, N.; Livingstone, M.S. Temporary disruption of the blood-brain barrier by use of ultrasound and microbubbles: Safety and efficacy evaluation in rhesus macaques. Cancer Res. 2012, 72, 3652-3663. [CrossRef] [PubMed]

149. Raymond, S.B.; Skoch, J.; Hynynen, K.; Bacskai, B.J. Multiphoton imaging of ultrasound/Optison mediated cerebrovascular effects in vivo. J. Cereb. Blood Flow Metab. 2007, 27, 393-403. [CrossRef] [PubMed]

150. Wu, S.Y.; Sanchez, C.S.; Samiotaki, G.; Buch, A.; Ferrera, V.P.; Konofagou, E.E. Characterizing focused-ultrasound mediated drug delivery to the heterogeneous primate brain in vivo with acoustic monitoring. Sci. Rep. 2016, 6, 37094. [CrossRef] [PubMed]

151. Song, K.H.; Fan, A.C.; Hinkle, J.J.; Newman, J.; Borden, M.; Harvey, B.K. Microbubble gas volume: A unifying dose parameter in blood-brain barrier opening by focused ultrasound. Theranostics 2017, 7, 144-152. [CrossRef] [PubMed]

152. Chu, P.C.; Chai, W.Y.; Tsai, C.H.; Kang, S.T.; Yeh, C.K.; Liu, H.L. Focused ultrasound-induced blood-brain barrier opening: Association with mechanical index and cavitation index analyzed by dynamic contrast-enhanced magnetic-resonance imaging. Sci. Rep. 2016, 6, 33264. [CrossRef] [PubMed]

153. Miller, D.B.; O'Callaghan, J.P. New horizons for focused ultrasound (FUS)-Therapeutic applications in neurodegenerative diseases. Metabolism 2017, 69, S3-S7. [CrossRef] [PubMed]

154. Sierra, C.; Acosta, C.; Chen, C.; Wu, S.Y.; Karakatsani, M.E.; Bernal, M.; Konofagou, E.E. Lipid microbubbles as a vehicle for targeted drug delivery using focused ultrasound-induced blood-brain barrier opening. J. Cereb. Blood Flow Metab. 2017, 37, 1236-1250. [CrossRef] [PubMed] 
155. Sun, T.; Samiotaki, G.; Wang, S.; Acosta, C.; Chen, C.C.; Konofagou, E.E. Acoustic cavitation-based monitoring of the reversibility and permeability of ultrasound-induced blood-brain barrier opening. Phys. Med. Biol. 2015, 60, 9079-9094. [CrossRef] [PubMed]

156. Poon, C.; McMahon, D.; Hynynen, K. Noninvasive and targeted delivery of therapeutics to the brain using focused ultrasound. Neuropharmacology 2017, 120, 20-37. [CrossRef] [PubMed]

157. Carpentier, A.; Canney, M.; Vignot, A.; Reina, V.; Beccaria, K.; Horodyckid, C.; Karachi, C.; Leclercq, D.; Lafon, C.; Chapelon, J.Y.; et al. Clinical trial of blood-brain barrier disruption by pulsed ultrasound. Sci. Transl. Med. 2016, 8, 343re2. [CrossRef] [PubMed]

158. Leinenga, G.; Gotz, J. Scanning ultrasound removes amyloid- $\beta$ and restores memory in an Alzheimer's disease mouse model. Sci. Transl. Med. 2015, 7, 278ra33. [CrossRef] [PubMed]

159. Torrice, M. Alzheimer's therapy goes acoustic. Chem. Eng. News 2015, 93, 5.

160. Keaney, J.; Walsh, D.M.; O’Malley, T.; Hudson, N.; Crosbie, D.E.; Loftus, T.; Sheehan, F.; McDaid, J.; Humphries, M.M.; Callanan, J.J.; et al. Autoregulated paracellular clearance of amyloid- $\beta$ across the blood-brain barrier. Sci. Adv. 2015, 1, e1500472. [CrossRef] [PubMed]

161. Alexopoulos, P.; Gleixner, L.S.; Werle, L.; Buhl, F.; Thierjung, N.; Giourou, E.; Kagerbauer, S.M.; Gourzis, P.; Kubler, H.; Grimmer, T.; et al. Plasma levels of soluble amyloid precursor protein $\beta$ in symptomatic Alzheimer's disease. Eur. Arch. Psychiatry Clin. Neurosci. 2017. [CrossRef] [PubMed]

162. Aryal, M.; Arvanitis, C.D.; Alexander, P.M.; McDannold, N. Ultrasound-mediated blood-brain barrier disruption for targeted drug delivery in the central nervous system. Adv. Drug Deliv. Res. 2014, 72, 94-109. [CrossRef] [PubMed]

163. Xie, F.; Boska, M.D.; Lof, J.; Uberti, M.G.; Tsutsui, J.M.; Porter, T.R. Effects of transcranial ultrasound and intravenous microbubbles on blood-brain barrier permeability in a large animal model. Ultrasound Med. Biol. 2008, 34, 2028-2034. [CrossRef] [PubMed]

164. Dasgupta, A.; Liu, M.; Ojha, T.; Storm, G.; Kiessling, F.; Lammers, T. Ultrasound-mediated drug delivery to the brain: Principles, progress and prospects. Drug Discov. Today Technol. 2016, 20, 41-48. [CrossRef] [PubMed]

165. Helfield, B.; Chen, X.; Watkins, S.C.; Villanueva, R.S. Biophysical insight into mechanisms of sonoporation. Proc. Natl. Acad. Sci. USA 2016, 113, 9983-9988. [CrossRef] [PubMed]

166. Van Rooij, T.; Skachkov, I.; Beekers, I.; Lattwein, K.R.; Voorneveld, J.D.; Kokhuis, T.J.; Bera, D.; Luan, Y.; van der Steen, A.F.; de Jong, N.; et al. Viability of endothelial cells after ultrasound-mediated sonoporation: Influence of targeting, oscillation, and displacement of microbubbles. J. Control. Release 2016, 238, 197-211. [CrossRef] [PubMed]

167. De Cock, I.; Zagato, E.; Braeckmans, K.; Luan, Y.; de Jong, N.; De Smedt, S.C.; Lentacker, I. Ultrasound and microbubble mediated drug delivery: Acoustic pressure as determinant for uptake via membrane pores or endocytosis. J. Control. Release 2015, 197, 20-28. [CrossRef] [PubMed]

168. Shapiro, G.; Wong, A.; Bez, M.; Yang, F.; Tam, S.; Even, L.; Sheyn, D.; Ben-David, S.; Tawackoli, W.; Pelled, G.; et al. Multiparameter evaluation of in vivo gene delivery using ultrasound-guided, microbubble-enhanced sonoporation. J. Control. Release 2016, 223, 157-164. [CrossRef] [PubMed]

169. Andreone, B.J.; Chow, B.W.; Tata, A.; Lacoste, B.; Ben-Zvi, A.; Bullock, K.; Deik, A.A.; Ginty, D.D.; Clish, C.B.; Gu, C. Blood-brain barrier permeability is regulated by lipid transport-dependent suppression of caveolae-mediated transcytosis. Neuron 2017, 94, 581-594.e5. [CrossRef] [PubMed]

170. Ben-Zvi, A.; Lacoste, B.; Kur, E.; Andreone, B.; Mayshar, Y.; Yan, H.; Gu, C. MFSD2A is critical for the formation and function of the blood-brain barrier. Nature 2014, 509, 507-511. [CrossRef] [PubMed]

171. Chow, B.W.; Gu, C. Gradual suppression of transcytosis governs functional blood-retinal barrier formation. Neuron 2017, 93, 1325-1333. [CrossRef] [PubMed]

172. Aw, M.S.; Paniwnyk, L.; Losic, D. The progressive role of acoustic cavitation for non-invasive therapies, contrast imaging and blood-tumor permeability enhancement. Expert Opin. Drug Deliv. 2016, 13, 1383-1396. [CrossRef] [PubMed]

173. Park, J.; Fan, Z.; Kumon, R.E.; El-Sayed, M.E.; Deng, C.X. Modulation of intracellular Ca ${ }^{2+}$ concentration in brain microvascular endothelial cells in vitro by acoustic cavitation. Ultrasound Med. Biol. 2010, 36, 1176-1187. [CrossRef] [PubMed]

174. Alonso, A.; Reinz, E.; Jenne, J.W.; Fatar, M.; Schmidt-Glenewinkel, H.; Hennerici, M.G.; Meairs, S. Reorganization of gap junctions after focused ultrasound blood-brain barrier opening in the rat brain. J. Cereb. Blood Flow Metab. 2010, 30, 1394-1402. [CrossRef] [PubMed] 
175. Alonso, A.; Reinz, E.; Fatar, M.; Hennerici, M.G.; Meairs, S. Clearance of albumin following ultrasound-induced blood-brain barrier opening is mediated by glial but not neuronal cells. Brain Res. 2011, 1411, 9-16. [CrossRef] [PubMed]

176. Aslund, A.K.O.; Snipstad, S.; Healey, A.; Kvale, S.; Torp, S.H.; Sontum, P.C.; de Lange Davies, C.; van Wamel, A. Efficient enhancement of blood-brain barrier permeability using acoustic cluster therapy (ACT). Theranostics 2017, 7, 23-30. [CrossRef] [PubMed]

177. Delalande, A.; Kotopoulis, S.; Postema, M.; Midoux, P.; Pichon, C. Sonoporation: Mechanistic insights and ongoing challenges for gene transfer. Gene 2013, 525, 191-199. [CrossRef] [PubMed]

178. Meairs, S. Facilitation of drug transport across the blood-brain barrier with ultrasound and microbubbles. Pharmaceutics 2015, 7, 275-293. [CrossRef] [PubMed]

179. Meng, Y.; Volpini, M.; Black, S.; Lozano, A.M.; Hynynen, K.; Lipsman, N. Focused US as a novel strategy for Alzheimer's disease therapeutics. Ann. Neurol. 2017, 81, 611-617. [CrossRef] [PubMed]

180. Horodyckid, C.; Canney, M.; Vignot, A.; Boisgard, R.; Drier, A.; Huberfeld, G.; François, C.; Prigent, A.; Santin, M.D.; Adam, C.; et al. Safe long-term repeated disruption of the blood-brain barrier using an implantable ultrasound device: A multiparametric study in a primate model. J. Neurosurg. 2017, 126, 1351-1361. [CrossRef] [PubMed]

181. O’Reilly, M.A.; Hough, O.; Hynynen, K. Blood-brain barrier closure time after controlled ultrasound-induced opening is independent of opening volume. J. Ultrasound Med. 2017, 36, 475-483. [CrossRef] [PubMed]

182. Sennoga, C.A.; Kanbar, E.; Auboire, L.; Dujardin, P.A.; Fouan, D.; Escoffre, J.M.; Bouakaz, A. Microbubble-mediated ultrasound drug-delivery and therapeutic monitoring. Expert Opin. Drug Deliv. 2017, 14, 1031-1043. [CrossRef] [PubMed]

183. Baranova, I.N.; Vishnyakova, T.G.; Bocharov, A.V.; Kurlander, R.; Chen, Z.; Kimelman, M.L.; Remaley, A.T.; Csako, G.; Thomas, F.; Eggerman, T.L.; et al. Serum amyloid A binding to CLA-1 (CD36 and LIMPII analogous-1) mediates serum amyloid A protein-induced activation of ERK1/2 and p38 mitogen-activated protein kinases. J. Biol. Chem. 2005, 280, 8031-8040. [CrossRef] [PubMed]

184. Wasan, K.M.; Brocks, D.R.; Lee, S.D.; Sachs-Barrable, K.; Thornton, S.J. Impact of lipoproteins on the biological activity and disposition of hydrophobic drugs: Implications for drug discovery. Nat. Rev. Drug Discov. 2008, 7, 84-99. [CrossRef] [PubMed]

185. Out, R.; Kruijt, J.K.; Rensen, P.C.; Hildebrand, R.B.; de Vos, P.; van Eck, M.; Van Berkel, T.J. Scavenger receptor BI plays a role in facilitating chylomicron metabolism. J. Biol. Chem. 2004, 279, 18401-18406. [CrossRef] [PubMed]

186. Rensen, P.C.N.; van Dijk, M.C.M.; Havenaar, E.C.; Bijsterbosch, M.K.; Kruijt, J.K.; van Berkel, T.J.C. Selective liver targeting of antivirals by recombinant chylomicrons: A new therapeutic approach to hepatitis $B$. Nat. Med. 1995, 1, 221-225. [CrossRef] [PubMed]

187. Williams, K.J.; Scanu, A.M. Uptake of endogenous cholesterol by a synthetic lipoprotein. Biochim. Biophys. Acta 1986, 875, 183-194. [CrossRef]

188. Levine, D.M.; Gordon, B.R.; Parker, T.S.; Rubin, A.L.; Saal, S.D.; Simon, S.R. Reconstituted HDL Particles and Uses Thereof. U.S. Patent No. 5,128,318A, 7 July 1992.

189. Lund-Katz, S.; Phillips, M.C. High-density lipoprotein structure-function and role in reverse cholesterol transport. Subcell Biochem. 2010, 51, 183-227. [PubMed]

190. Lacko, A.G.; Nair, N.; Prokai, L.; McConathy, W.J. Prospects and challenges of the development of lipoprotein-based formulations for anti-cancer drugs. Expert Opin. Drug Deliv. 2007, 4, 665-675. [CrossRef] [PubMed]

191. Azeem, A.; Rizwan, M.; Ahmad, F.J; Iqbal, Z.; Khar, R.K.; Aqil, M.; Talegaonkar, S. Nanoemulsion components screening and selection: A technical note. AAPS PharmSciTech 2009, 10, 69-76. [CrossRef] [PubMed]

192. Sagar, G.H.; Arunagirinathan, M.A.; Bellare, J.R. Self-assembled surfactant nano-structures important in drug-delivery: A review. Indian J. Exp. Biol. 2007, 45, 133-159.

193. Anton, N.; Benoit, J.P.; Saulnier, P. Design and production of nanoparticles formulated from nano-emulsion templates: A review. J. Control. Release 2008, 128, 185-199. [CrossRef] [PubMed]

194. Bansal, T.; Mustafa, G.; Khan, Z.I.; Ahmad, F.J.; Khar, R.K.; Talegaonkar, S. Solid self-nanoemulsifying delivery systems as a platform technology for formulation of poorly soluble drugs. Crit. Rev. Ther. Drug Carrier Syst. 2008, 25, 63-116. [CrossRef] [PubMed] 
195. Sadurni, N.; Solans, C.; Azemar, N.; Garcia-Celma, M.J. Studies on the formation of O/W nano-emulsions, by low-energy emulsification methods, suitable for pharmaceutical applications. Eur. J. Pharm. Sci. 2005, 26, 438-445. [CrossRef] [PubMed]

196. Tresset, G. The multiple faces of self-assembled lipidic systems. PMC Biophys. 2009, 2, 3. [CrossRef] [PubMed]

197. Hato, M.; Yamashita, J.; Shiono, M. Aqueous phase behavior of lipids with isoprenoid type hydrophobic chains. J. Phys. Chem. B 2009, 113, 10196-10209. [CrossRef] [PubMed]

198. Barauskas, J.; Cervin, C.; Tiberg, F.; Johnsson, M. Structure of lyotropic self-assembled lipid nonlamellar liquid crystals and their nanoparticles in mixtures of phosphatidyl choline and $\alpha$-tocopherol (vitamin E). Phys. Chem. Chem. Phys. 2008, 10, 6483-6485. [CrossRef] [PubMed]

199. Efrat, R.; Aserin, A.; Garti, N. On structural transitions in a discontinuous micellar cubic phase loaded with sodium diclofenac. J. Colloid Interface Sci. 2008, 321, 166-176. [CrossRef] [PubMed]

200. Yaghmur, A.; Laggner, P.; Almgren, M.; Rappolt, M. Self-assembly in monoelaidin aqueous dispersions: Direct vesicles to cubosomes transition. PLoS ONE 2008, 3, e3747. [CrossRef] [PubMed]

201. Yaghmur, A.; Glatter, O. Characterization and potential applications of nanostructured aqueous dispersions. Adv. Colloid Interface Sci. 2009, 147-148, 333-342. [CrossRef] [PubMed]

202. Vandoolaeghe, P.; Rennie, A.R.; Campbell, R.A.; Nylander, T. Neutron reflectivity studies of the interaction of cubic phase nanoparticles with phospholipid bilayers of different coverage. Langmuir 2009, 25, 4009-4020. [CrossRef] [PubMed]

203. Vandoolaeghe, P.; Barauskas, J.; Johnsson, M.; Tiberg, F.; Nylander, T. Interaction between lamellar (vesicles) and nonlamellar lipid liquid-crystalline nanoparticles as studied by time-resolved small-angle X-ray diffraction. Langmuir 2009, 25, 3999-4008. [CrossRef] [PubMed]

204. Yaghmur, A.; Kriechbaum, M.; Amenitsch, H.; Steinhart, M.; Laggner, P.; Rappolt, M. Effects of pressure and temperature on the self-assembled fully hydrated nanostructures of monoolein-oil systems. Langmuir 2010, 26, 1177-1185. [CrossRef] [PubMed]

205. Fong, W.K.; Hanley, T.; Boyd, B.J. Stimuli responsive liquid crystals provide "on-demand" drug delivery in vitro and in vivo. J. Control. Release 2009, 135, 218-226. [CrossRef] [PubMed]

(C) 2018 by the author. Licensee MDPI, Basel, Switzerland. This article is an open access article distributed under the terms and conditions of the Creative Commons Attribution (CC BY) license (http:/ / creativecommons.org/licenses/by/4.0/). 